\title{
Peramalan Gelombang Covid 19 Menggunakan Hybrid Nonlinear Regression Logistic - Double Exponential Smoothing di Indonesia dan Prancis
}

\author{
I Gusti Bagus Ngurah Diksa ${ }^{*}$ \\ ${ }^{1}$ Departemen Statistika, Fakultas Sains dan Analitika Data, Institut Teknologi Sepuluh Nopember, \\ Jl. Arif Rahman Hakim, Kota Surabaya 60111, Jawa Timur, Indonesia \\ *Penulis Korespondensi. Email:n16diksa@gmail.com
}

\begin{abstract}
ABSTRAK
Indonesia dan Prancis adalah dua Negara yang mengalami Covid 19 dengan pola pergerakan kasus Covid 19 yang berbeda. Kondisi Indonesia masih mengalami siklus one wave namun Prancis sudah masuk pada pola second wave. Makna second wave adalah kondisi epidemi Covid 19 yang baru muncul setelah epidemi sebelumnya dianggap selesai. Dalam peramalan kasus Covid 19 baik itu terkait informasi puncak dari terjadinya kasus Covid 19 serta ramalan terkait akan berakhirnya pandemi kasus Covid 19 suatu negara merupakan hal penting bagi pemerintah suatu Negara. Model hybrid meningkatkan akurasi ramalan dibandingkan model time series yang dilakukan secara terpisah. Tujuan penelitian ini adalah melakukan peramalan kasus Covid 19 di Indonesia dan Prancis dengan menggunakan metode hybrid dan membandingkan dengan peramalan dengan salah satu metode tunggal. Metode yang digunakan adalah metode tunggal yaitu Nonlinear Regression Logistic dan metode Hybrid Nonlinear Regression Logistic-Double Eksponensial Smoothing. Hasilnya adalah model peramalan Hybrid Nonlinear Regression Logistic and Doubel Exponential Smoothing lebih bagus digunakan dalam peramalan kasus Covid 19 di Indonesia dan Prancis. Terlihat bahwa nilai MAPE model Hybrid Nonlinear Regression Logistic-Double Eksponensial Smoothing jauh lebih kecil dibandingkan model peramalan Nonlinear Regression Logistic.
\end{abstract}

Kata Kunci:

Covid 19; Peramalan; Nonlinear Regression Logistic; Double Exponential Smoothing

\section{ABSTRACT}

Indonesia and France are two countries that have experienced Covid 19 with different patterns of movement of Covid 19 cases. Indonesia's condition is still experiencing a one wave cycle but France has entered into the second wave pattern. The meaning of the second wave is the condition of the Covid 19 epidemic which only emerged after the previous epidemic was considered over. In forecasting the Covid 19 case, whether it is related to the peak information on the occurrence of the Covid 19 case and predictions regarding the end of the pandemic of the Covid 19 case in a country, it is important for the government of a country. The hybrid model improves forecast accuracy compared to the time series model which is carried out separately. The purpose of this study is to forecast the cases of Covid 19 in Indonesia and France using the hybrid method and comparing with forecasting with one single method. The method used is a single method, namely Nonlinear Logistic Regression and Hybrid Nonlinear Regression Logistic-Double Exponential Smoothing methods. The result is that the Hybrid Nonlinear Regression Logistic and Double Exponential Smoothing forecasting model is better used in forecasting the Covid 19 cases in Indonesia and France. It can be seen that the MAPE value of the

e-ISSN: 2656-1344 (C) 2021 I.G.B.N. Diksa | Under the licence CC BY-NC 4.0

Received: 2 November 2020 | Accepted: 24 December 2020 | Online: 2 January 2021 
Hybrid Nonlinear Regression Logistic - Double Exponential Smoothing model is much smaller than the Nonlinear Regression Logistic forecasting model.

Keywords:

Covid 19; Forecasting; Nonlinear Regression Logistic; Double Exponential Smoothing

Format Sitasi:

I.G.B.N. Diksa, "Peramalan Gelombang Covid 19 Menggunakan Hybrid Nonlinear Regression Logistic-Double Exponential Smoothing di Indonesia dan Prancis," Jambura J. Math., vol. 3, no. 1, pp. 37-51, 2021

\section{Pendahuluan}

Tahun 2020 merupakan waktu yang berat bagi berlangsungnya kehidupan di negara negara yang ada di dunia. Semua pergerakan baik ekonomi dan sosial terhambat akibat pandemic wabah COVID 19 (Corona Virus Diseases 2019). Wabah Covid 19 disinyalir pertama kali terdeteksi di kota Wuhan China. Virus ini menyebar cepat dan menginfeksi banyak penduduk di dunia. Jumlah kasus Covid 19 di dunia telah mencapai 44.574.981 kasus. Berbagai macam upaya dan kebijakan dari pemerintah masing masing negara dibuat guna menekan kasus covid 19 tersebut.

Dewasa ini terdapat istilah "second wave" dalam perkembangan kasus Covid 19 di beberapa negara. Menurut Staf Departemen Ilmu Kesehatan Masyarakat Fakultas Kedokteran Universitas Padjadjaran, Panji Fortuna Hadisoemarto pada website istilah second wave adalah kondisi epidemi covid 19 yang baru muncul setelah epidemi sebelumnya dianggap selesai. Pemicu munculnya gelombang ini disebabkan adanya injeksi virus Covid 19 ke populasi yang tidak memiliki kekebalan kelompok atau herd immunity. Kondisi ini akan menyebabkan pemulihan kegiatan sosial ekonomi suatu Negara terhambat dalam arah perbaikan akibat kondisi yang pertama.

Negara negara eropa telah kembali berada pada kebangkitan kasus Covid 19 dengan titik kebangkitan pada wilayah Inggris, Spanyol dan Prancis yang masing masing melaporkan adanya kasus baru harian yang bermunculan. Tingkat infeksi sekarang lebih tinggi daripada yang terjadi pada bulan Maret dan April di banyak negara. Prancis menjadi salah satu Negara di eropa yang mengalami second wave yang menunjukkan bahwa adanya elemen kelelahan karena pembatasan setelah berbulanbulan pembatasan pada kehidupan sehari-hari dan dengan ekonomi yang goyah. Selama gelombang pertama pada negara tersebut, jumlah kasus baru harian Prancis mencapai puncaknya lebih dari 7.500 pada 31 Maret. Jumlah kasus barunya tercatat pada hari Minggu tanggal 25 Oktober 2020 dengan 26.675 kasus baru yang nilai tersebut lebih dari tiga kali lebih tinggi dari puncak pertama namun hal tersebut masih meningkat dan belum menemukan kondisi puncak.

Berbeda dengan Prancis, Indonesia masih merupakan Negara yang dalam kasus covidnya masih dalam satu gelombang. Indonesia merupakan Negara yang juga merasakan dampak pandemic global covid 19. Kasus penyebaran virus ini terdeteksi pada tanggal 2 maret 2020. Sampai pada akhir Juli 2020, kasus covid masih menunjukkan trend yang positif. Terbukti kondisi covid 19 pada tanggal 26 oktober 2020, kasus covid 19 terus bertambah hingga totalnya mencapai 389.712 kasus. Melihat perkembangan jumlah orang yang terinfeksi posiif covid 19 yang semakin meningkat maka hal tersebut memerlukan peramalan peramalan guna pengambilan kebijakan oleh pemerintah. 
Dalam peramalan kasus Covid 19 baik itu terkait informasi puncak dari terjadinya kasus Covid 19 dan ramalan terkait akan berakhirnya pandemic kasus covid 19 yang berada pada Negara yang mengalami satu gelombang maupun dua gelombang merupakan hal penting bagi penanggung jawab suatu Negara. Oleh karena itu para peneliti berusaha melakukan permodelan peramalan akan keberlangsungan Covid 19 ini. Kasus covid 19 mengikuti pola tertentu yang mana pola ini berdasarkan pada transmisi yang dinamis dari epidemi. Setiap epidemi di suatu Negara telah muncul dengan segi besaran yang berbeda dari waktu ke waktu, terutama ketika perubahan periode cuaca dan penyebaran virus selama periode tersebut sehingga membentuk pola nonlinear [1]. Petropoulus dan Makridakis menemukan bahwa data covid 19 di masa lalu tidak akan memberi peran seperti biasa dengan menggunakan analisis perkiraan deret waktu sederhana. Hal ini disebabkan karena meramalkan masa depan epidemi ini jauh lebih sulit karena kasusnya tumbuh secara eksponensial dan datanya tidak Linear serta tidak stasioner [2]. Menurut Sri Harini, dengan menggunakan analisis pendekatan time series ditemukan bahwa model sebaran Covid 19 di Indonesia mengikuti model double exponential [3]. Model ARIMA (Autoregressive Integrated Moving Average) berbasis Box-Jenkins adalah model statistik yang banyak digunakan dalam analisis deret waktu, yang mencakup berbagai macam pola, mulai dari deret waktu stasioner hingga non-stasioner dan musiman (periodik). Namun, dalam menangani situasi nonlinear di mana data bukan merupakan fungsi Linear waktu, penggunaan metodologi Box-Jenkins tidak tepat [4]. Dalam situasi ini, peramalan kasus Covid 19 dengan menggunakan model tunggal dirasa kurang efektif. Diperlukan model yang lebih kompleks lagi dalam menjelaskan kasus Covid 19. Model hybrid merupakan solusi yang tepat dalam menjelaskan kasus Covid 19 yang terjadi saat ini dimana data tersebut mengandung pola nonlinear dan Linear. Penggunaan model hybrid mampu meningkatkan akurasi ramalan dibandingkan model time series yang dilakukan secara terpisah [5]. Pada kasus Covid 19 di dunia, pernah dilakukan penelitian yang memprediksi trend epidemic Covid 19 dengan menggunakan Nonlinear Regression Logistic Model [6]. Penggunaan model hybrid antara model Nonlinear dengan model Linear memberikan keuntungan dalam meningkatkan akurasi peramalan [13]. Model peramalan Double Exponential Smoothing merupakan salah satu model linear yang equivalen dengan ARIMA $(0,2,2)$ [14]. Selain itu, Model tersebut juga sangat efisien untuk data yang mempunyai pola trend [15]. Oleh karena itu, penelitian ini menggunakan model Hybrid Nonlinear - Linear yaitu Hybrid Nonlinear Regression Logistic (NRL)-Double Eksponensial Smoothing (DES) dalam melakukan peramalan kasus covid 19 di Indonesia dan Prancis kemudian dibandingkan dengan menggunakan nilai Mean Absolute Percentage Error (MAPE) terkecil.

\section{Metode}

\subsection{Nonlinear Regression Logistic Model}

Untuk banyak data pertumbuhan, rata rata pertumbuhan tidak terus menurun, melainkan naik hingga maksimum sebelum terus menurun hingga 0. Hal ini ditunjukkan dalam kurva pertumbuhan dengan bentuk - $S$ atau sigmoidal. Misalkan banyaknya populasi pada waktu $\mathrm{t}$ adalah $\mathrm{N}(\mathrm{t})$, maka laju perubahan populasi terhadap waktu $\mathrm{t}$ adalah $\frac{d N(t)}{d t}$. Selanjutnya jika laju perubahan populasi sebanding dengan banyaknya populasi yang ada, maka: 


$$
\frac{d N(t)}{d t}=k N(t)
$$

dengan $k$ konstanta dan disebut laju reproduksi [16]. Jika laju reproduksi tidak konstan, maka $k$ dapat dipandang sebagai suatu fungsi dari variabel $N$, misalkan $f(N)$. maka model persamaan (1) dapat diubah menjadi:

$$
\frac{d N(t)}{d t}=N(t) f(N(t))
$$

Dari model persamaan pertumbuhna eksponensial (1) dapat ditentukan suatu model baru yaitu persamaan pertumbuhan logistik (2).

Pertumbuhan logistik adalah model pertumbuhan populasi yang terkait dengan kepadatan yang mencerminkan pengaruh dari persaingan intraspesifik. Penghambatan pertumbuhan populasi dapat dijelaskan secara matematika dengan menambahkan variabel yang menjelaskan pengaruh kepadatan ke dalam persamaan eksponensial.

Dari persamaan (2), asumsi sederhana yang dapat dibuat adalah $f(N(t)$ ) berbentuk Linear, yaitu $N(t)=c_{1} N(t)+c_{2}$. Jika kita menggunakan kondisi $f(0)=r$ dimana $\mathrm{r}$ adalah laju pertumbuhan dan dan $\mathrm{f}(\mathrm{K})=0$ (" $\mathrm{K}$ " adalah carrying capacity atau ambang batas populasi), maka kita dapat menemukan $c_{2}=r$ dan $c_{1}=-r / k$. Jadi diperoleh bentuk $f(N(t))=r-\frac{r}{k} N(t)$. Oleh karena itu, persamaan logistic dengan $\mathrm{f}(\mathrm{N}(\mathrm{t}))$ Linear adalah

$$
\frac{d N(t)}{d t}=\left(r-\frac{r}{k} N(t)\right) N(t)=\left(1-\frac{1}{k} N(t)\right) r N(t)
$$

Dengan pertumbuhan populasi maka nilai $\frac{d N(t)}{d t}$ akan berkurang secara konstan sampai pada ambang batas populasi $\mathrm{K}$

Persamaan (3) mempunyai solusi analitik $N(t)=\frac{K}{1+\left(\frac{K}{N_{0}}-1\right) e^{-r t}}$ [7]. Jika dilambangkan dengan parameter theta $(\theta)$ maka

$$
f\left(x_{t}, \theta\right)=\frac{\theta_{1}+\left(\theta_{2}-\theta_{1}\right)}{\left(1+\exp \left(\frac{x_{t}-\theta_{3}}{\theta_{4}}\right)\right)}
$$

\subsection{Double Exponential Model}

Metode double exponential smoothing digunakan jika data tersebut menunjukkan adanya trend. Dengan analogi yang dipakai pada waktu berangkat dari rata-rata bergerak tunggal (Single Moving Average) ke pemulusan eksponensial tunggal (Single Eksponential Smoothing) maka dapat pula berangkat dari rata-rata bergerak ganda (Double Moving Average) ke pemulusan eksponensial ganda (Double Eksponential Smoothing). Perpindahan seperti itu mungkin menarik karena salah satu keterbatasan dari Single Moving Average (yaitu perlunya menyimpan $\mathrm{n}$ nilai terakhir) masih terdapat pada Double Moving Average. Double Eksponential Smoothing dapat dihitung hanya dengan tiga nilai data dan satu nilai untuk $a$. Pendekatan ini juga memberikan bobot yang semakin menurun pada observasi masa lalu. Dengan alasan ini Double 
Eksponential Smoothing lebih disukai daripada Double Moving Average sebagai suatu metode peramalan dalam berbagai kasus utama [12]. Metode ini dibagi menjadi dua yaitu double exponential smoothing satu parameter dari Brown dan dua parameter dari Holt. Metode double exponential smoothing satu parameter dari Brown dikembangkan untuk mengatasi perbedaan yang muncul antara data aktual dan nilai peramalan apabila ada trend pada pola datanya. Adapun rumus yang digunakan dalam metode double exponential smoothing satu parameter dari Brown adalah

$$
\begin{gathered}
S_{t}^{\prime}=a X_{t}+(1-\alpha) S_{t-1}^{\prime} \\
S_{t}^{\prime \prime}=a S_{t}+(1-\alpha) S_{t-1}^{\prime \prime} \\
a_{t}=S_{t}^{\prime}+\left(S_{t}^{\prime}-S_{t}^{\prime \prime}\right)=2 S_{t}^{\prime}-S_{t}^{\prime \prime} \\
b_{t}=\frac{\alpha}{1-\alpha}\left(S_{t}^{\prime}-S_{t}^{\prime \prime}\right) \\
F_{t+m}=a_{t}+b_{t} m
\end{gathered}
$$

Dimana

$S_{t}^{\prime} \quad$ : Nilai single exponential smoothing periode ke $t$

$\alpha \quad$ : Parameter exponential smoothing $(0<\alpha<1)$

$X_{t} \quad$ : Data aktual pada periode $\mathrm{t}$

$S_{t-1}^{\prime} \quad$ : Nilai single exponential smoothing periode ke $t-1$

$S_{t}^{\prime \prime} \quad$ : Nilai double exponential smoothing periode ke $t$

$S_{t-1}^{\prime \prime} \quad$ : Nilai double exponential smoothing periode ke $t-1$

$a_{t} \quad$ : Nilai konstanta pada periode ke- $t$

$b_{t} \quad$ : Nilai trend pada periode ke- $t$

$\mathrm{m} \quad$ : Periode ke depan yang akan diramalkan

$F_{t+m} \quad$ : Nilai peramalan untuk $m$ periode ke depan

Metode double eksponential smoothing Linear dari Holt memuluskan nilai trend dengan parameter yang berbeda dari parameter yang digunakan pada pemulusan data yang asli. Adapun rumus yang digunakan dalam metode double exponential smoothing dua parameter dari Holt dapat dilihat pada persamaan berikut:

$$
\begin{gathered}
S_{t}^{\prime}=a X_{t}+(1-\alpha)\left(S_{t-1}^{\prime}+b_{t-1}\right) \\
b_{t}=\gamma\left(S_{t}^{\prime}-S_{t-1}^{\prime}\right)+(1-\gamma) b_{t-1} \\
F_{t+m}=S_{t}^{\prime}+b_{t} m
\end{gathered}
$$

Dengan $\gamma$ adalah Nilai parameter pemulusan trend $0<\gamma<1$ [8].

Proses inisialisasi untuk pemulusan eksponensial ganda dari Holt memerlukan dua taksiran, yaitu $S_{t}$ dan $b_{t}$. proses inisialisasi, diawali dengan memilih $S_{1}=X_{1}$ sedangkan untuk taksiran trend didapat dari rumus $b_{1}=X_{2}-X_{1}$. Adapun konstanta pemulusan a dan $\gamma$ dalam metode peramalan double exponential smoothing berperan sebagai faktor pembobotan. Nilai a dan $\gamma$ bernilai dekat dengan satu, ramalan terbaru akan menyertakan penyesuaian yang besar untuk setiap kesalahan yang terjadi pada ramalan sebelumnya. Sebaliknya jika $\alpha$ dan $\gamma$ dekat dengan nol, ramalan terbaru akan sangat mirip dengan nilai yang lama. 


\subsection{Model Hybrid Nonlinear Regression Logistic (NRL)-Doubel Eksponensial Smoothing (DES)}

Metode kombinasi series hybrid structure telah ditemukan pada konsep dari prosedur model sequensial. Model series hybrid structure ini diimplementasikan pertama kali oleh zhang [9] pada dunia time series forecasting. Penelitian tersebut membuktikan bahwa dengan menguraikan deret waktu menjadi bagian Linear dan nonlinear ataupun sebaliknya serta memodelkannya dengan ARIMA dan MLP (Multi Layer Perceptron). Karena pemorsesan output model dengan model ARIMA dan MLP, kinerja yang unggul dapat dicapai terhadap komponen individu yang digunakan secara terpisah. Berdasarkan Gambar 1, kerangka model series merupakan nilai yang diprakirakan dari model pertama yang diterapkan pada data awal dan nilai yang diprakirakan dari model kedua yang diterapkan dari hasil peramalan model sebelumnya dan oleh karena itu, nilai teresebut merupakan nilai prakiraan model terakhir yang diterapkan pada hasil prakiraan model $(n-1)$.

Nonlinear Regression Logistic merupakan fungsi pendekatan model nonlinear yang dapat menangkap bentuk non liniier pada data runtun waktu sedangkan Double Exponential Smoothing adalah model Linear yang dapat menangkap karakteristik Linear data runtun waktu. Model Nonlinear Regression Logistic (NRL) dan Double Eksponensial Smoothing (DES) memiliki kemampuan model yang bagus dalam lingkupnya masing masing yaitu Nonlinear dan Linear. Namun tidak ada satupun yang merupakan model yang dapat universal digunakan sesuai kondisi data. Dalam dunia nyata pola series data sering ditemukan mengandung pola Linear dan non liner sekaligus. Oleh karena itu, kombinasi model ini mampu menggabungkan keunggulan dari masing-masing model Nonlinear Regression Logistic (NRL) dan Double Eksponensial Smoothing (DES) dalam menangkap karakteristikdata dengan pola nonlinear maupun nonlinear.

Dalam model hybrid ini, data deret waktu diasumsikan terdiri dari komponen nonlinear dan linear. Secara umum model data deret waktu yang merupakan kombinasi komponen Nonlinear dan linear secara sistematis ditulis sebagai,

$$
Y_{t}=N_{t}+L_{t}
$$

Dengan $Y_{t}$ merupakan data deret waktu pada waktu ke- $t, N_{t}$ merupakan komponen nonlinear waktu ke- $t$ dan $L_{t}$ merupakan komponen linear waktu ke-t. tahap pertama dalam membentuk model Hybrid Nonlinear Regression Logistic-Double Eksponensial Smoothing adalah membentuk komponen nonlinear. Komponen nonlinear dimodelkan dengan menggunakan model Regression Nonlinear Logistic yang mana input data yang digunakan merupakan input data deret waktu (sampel in). Hasil prediction dari model Regression Nonliniear Logistic selanjutnya disebut sebagai komponen nonLinear. Kemudian residual dari model Regression Logistic diasumsikan tidak memenuhi asumsi white noise. Residual dari model komponen nonlinear menggunakan Regression Nonlinear Logistic dituliskan sebagai

$$
\varepsilon_{t}=Z_{t}-\widehat{N}
$$

Dengan $\varepsilon_{t}$ merupakan residual model Regression Nonlinear Logistic waktu ke- $t$ dan $\hat{L}_{t}$ merupakan komponen linear waktu ke-t hasil ramalan dari nilai prediksi model Regression Nonlinear Logistic. Setelah komponen nonlinear terbentuk, langkah 
selanjutnya adalah membentuk komponen linear. Komponen linear dimodelkan menggunakan model Double Exponetial Smoothing dengan data yang digunakan merupakan residual dari model Regression Nonlinear Logistic. Selanjutnya untuk mendapatkan nilai hybrid dilakukan penggabungan komponen Nonlinear dengan Linear yaitu model Hybrid Nonlinear Regression Logistic - Double Eksponensial Smoothing dapat dinyatakan sebagai

$$
\hat{Z}_{t}=\widehat{N}_{t}+\widehat{L}_{t}
$$

Dengan $\hat{Z}_{t}$ merupakan model peramalan Hybrid Nonlinear Regression Logistic - Double Eksponensial Smoothing, $\widehat{N}_{t}$ merupakan komponen nonlinear waktu ke- $t$ hasil ramalan dari model Regression Logistic dan $\hat{L}_{t}$ komponen linear waktu ke- $t$ hasil peramalan $\hat{\varepsilon}_{t}$ pada persamaan [9].

\subsection{Kriteria Model Terbaik}

Dalam melakukan prediksi, kebaikan hasil ramalan suatu model sangat menentukan keputusan apakah model tersebut efisien dalam membuat hasil ramalan. Tingkat kesalahan peramalan tersebut dapat dihitung melalui ukuran kesalahan peramalan dengan menggunakan MAPE (Mean Absolute Percentage Error).

MAPE adalah ukuran ringkasan yang paling sering digunakan untuk mengevaluasi keakuratan prakiraan populasi. Ukuran ini memberikan petunjuk seberapa besar kesalahan peramalan dibandingkan dengan nilai sebenarnya. MAPE digunakan untuk mengukur ketepatan nilai dugaan model yang dinyatakan dalam bentuk rata-rata persentase absolut kesalahan dan lebih banyak digunakan untuk perbandingan pada data-data yang mempunyai skala interval waktu berbeda. Hasil peramalan dikatakan semakin akurat jika nilai MAPE semakin kecil [8]. Secara matematis dapat ditulis sebagai berikut

$$
M A P E=\left(\frac{1}{n} \sum_{t=1}^{n}\left|\frac{y(t)-y^{\prime}(t)}{y(t)}\right|\right) \times 100
$$

dengan $\mathrm{y}_{t}$ adalah nilai observasi pada waktu ke- $t, y_{t}^{\prime}$ adalah nilai peramalan pada waku ke- $t$ dan $n$ adalah banyaknya observasi. Model yang baik memiliki nilai MAPE sesuai kriteria pada Tabel 1.

Tabel 1. Kriteria MAPE

\begin{tabular}{cl}
\hline Nilai MAPE $(\%)$ & \multicolumn{1}{c}{ Kriteria } \\
\hline$<10$ & Kemampuan peramalan sangat baik \\
$10-20$ & Kemampuan peramalan baik \\
$20-50$ & Kemampuan peramalan cukup \\
$>50$ & Kemampuan peramalan buruk \\
\hline
\end{tabular}

Sumber: [10] 


\section{Hasil dan Pembahasan}

\subsection{Gambaran Covid 19 di Indonesia dan Prancis}

Dalam penelitian ini, data yang digunakan adalah data harian total kasus dan jumlah kasus baru Covid 19 di Indonesia dan Prancis. Dalam pembentukan model peramalan akan digunakan total kasus Covid 19 di kedua Negara tersebut sedangkan data jumlah kasus baru covid 19 berfungsi untuk melihat fit model dalam bentuk grafik antara differencing hasil prediksi model total kasus dengan kasus baru covid 19. Dalam pembentukan model data dibagi menjadi dua bagian yaitu data training dan data testing. Data training pada Indonesia dimulai dari kasus pertama yaitu tanggal 2 Maret 2020 sampai tanggal 3 Oktober 2020 dengan total data yang digunakan adalah 216 data. Untuk data testing didapat dari tanggal 4 - 24 Oktober 2020 sebanyak 21 data. Untuk kasus pada Negara Prancis digunakan sebanyak 253 data yaitu dari tanggal 25 Januari - 3 Oktober 2020 dan data testing yang digunakan mulai tanggal 4 - 24 Oktober 2020 sebanyak 21 data. Hal tersebut dapat digambarkan pada Gambar 1.
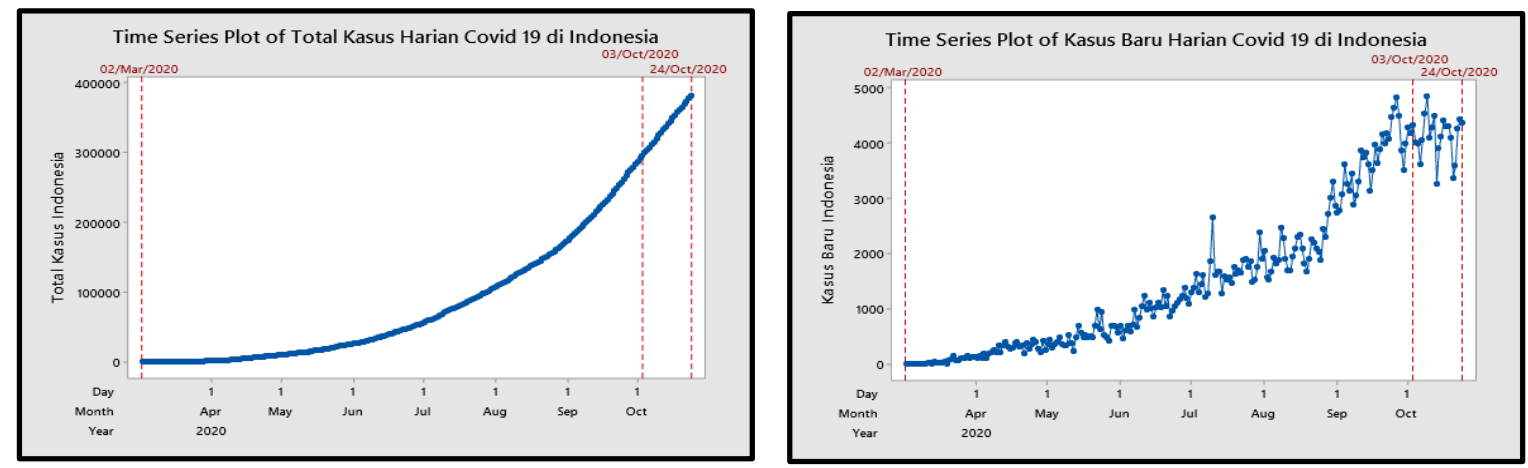

Gambar 1. Time series plot total kasus dan kasus baru harian covid 19 di Indonesia

Berdasarkan Gambar 1, terlihat bahwa kondisi kasus Covid 19 belum mengalami perbaikan ke arah trend munculnya kasus Covid. Jumlah penderita Covid 19 setiap harinya bertambah dan belum mengalami penurunan yang signifikan. oleh karena itu, pola grafik pada Indonesia masih berupa satu gelombang. Pada tanggal 25 oktober 2020, jumlah pasien yang terinfeksi Covid-19 di Indonesia bertambah sebanyak 4.070 orang pada hari jumat (23 Oktober 2020). Adapun kasus baru pasien konfirmasi positif Covid-19 tersebar di 34 provinsi. Dari data itu, tercatat lima provinsi dengan penambahan kasus baru tertinggi. Kelima provinsi itu, yakni DKI Jakarta (1.062 kasus baru), Jawa Barat (421 kasus baru), Riau (380 kasus baru), Sumatera Barat (300 kasus baru), Jawa Timur (289 kasus baru). Sementara itu, penularan Covid-19 secara keseluruhan hingga saat ini terjadi di 501 kabupaten/kota yang berada di 34 provinsi. Oleh karena itu, akumulasi orang yang terpapar virus corona di Tanah Air mencapai 389.712 kasus. Dari berita tersebut dapat disimpulkan memang benar Indonesia belum mengalami penurunan kasus Covid 19 secara signifikan.

Berdasarkan Gambar 2, terlihat bahwa Prancis pernah mengalami masa puncak dari kasus Covid 19. Namun setelah keadaan kasus Covid 19 menurun dan stasioner, tiba tiba muncul kembali kasus Covid 19 di Prancis. Penambahan ini sangat lah banyak hingga belum mencapai puncak. Dalam keadaan ini Negara Prancis memasukin second wave dalam kemunculan kasus Covid 19. Isu second wave sangat gencar terdengar di 
Negara Prancis. Perdana Menteri Prancis, Jean Castex memberikan kebijakan terkait pengendalian dari menyebarnya wabah Covid 19 di Prancis seperti adanya jam malam. Keputusan ini dibuat ketika mendapat kabar bahwa kasus baru Covid 19 di Prancis memecahkan rekor 41.620 kasus baru di hari kamis 22 oktober 2020.
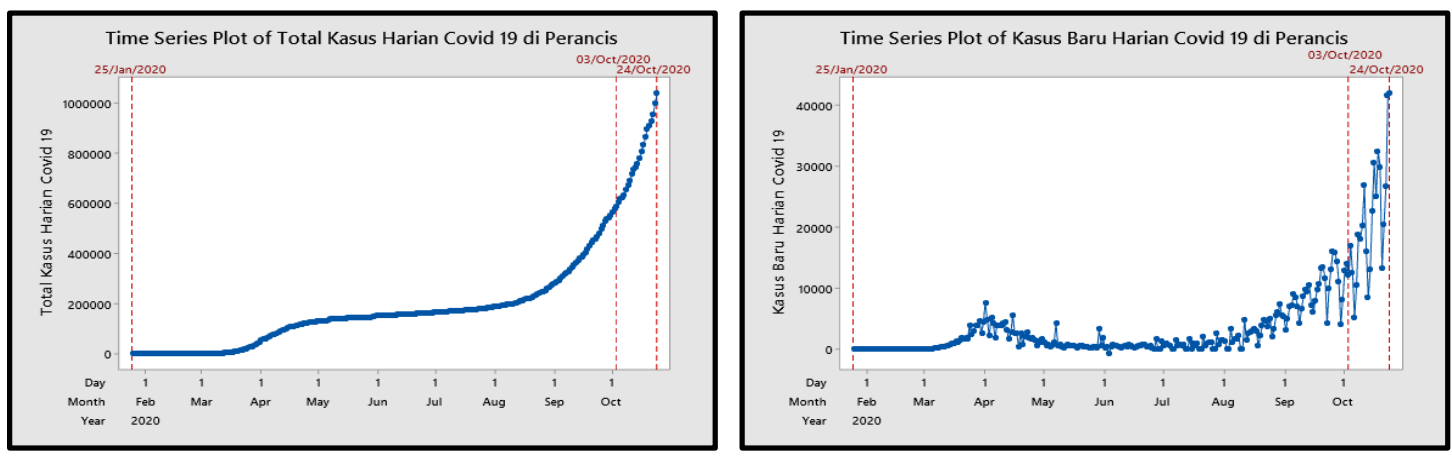

Gambar 2. Time series plot total kasus dan kasus baru harian covid 19 di Prancis

\subsection{NonLinear Regression Logistics Time Series}

Dalam pembuatan model nonLinear regression logistic maka diperlukan identifikasi parameter theta guna mendapatkan model yang fit. Mengingat kasus Covid 19 di Indonesia masih tergolong one wave maka cukup menggunaan satu model nonLinear regression logistic. Theta 1 yang diperkirakan adalah $1.000 .000-1.500 .000$ total kasus covid yang akan terjadi di Indonesia. Parameter theta 4 yang fit diperoleh dengan menggunakan nilai awal terlebih dahulu dan selanjutnya disajikan pada Tabel 2.

Tabel 2. Pembentukan model nonlinear regression logistic dengan initial value $\theta_{4}$

\begin{tabular}{ccccc}
\hline \multirow{2}{*}{ Prakiraan Kasus } & \multicolumn{4}{c}{ Parameter } \\
\cline { 2 - 5 } & $\boldsymbol{\theta}_{\mathbf{1}}{ }^{*}$ & $\boldsymbol{\theta}_{\mathbf{2}}{ }^{*}$ & $\boldsymbol{\theta}_{\mathbf{3}}$ & $\boldsymbol{\theta}_{\mathbf{4}}$ \\
\hline 1.000 .000 & 1.000 .000 & 0 & 209 & 1 \\
1.100 .000 & 1.100 .000 & 0 & 209 & 1 \\
1.200 .000 & 1.200 .000 & 0 & 209 & 1 \\
1.300 .000 & 1.300 .000 & 0 & 209 & 1 \\
1.400 .000 & 1.400 .000 & 0 & 209 & 1 \\
1.500 .000 & 1.500 .000 & 0 & 209 & 1 \\
\hline
\end{tabular}

Keterangan: * locked value

Setelah mendapatkan parameter yang fit dari hasil initial value pada Tabel 2, maka dapat dilanjutkan pembentukan model dari parameter yang fit sesuai pada Tabel 3. Tabel 3 merupakan hasil dari model nonlinear regression logistic dengan 6 kemungkinan total kasus covid 19 yang akan dialami. Mengingat Indonesia belum mengalami tanda tanda penurunan maka diberikan beberapa spekulasi pesimistis apabila kasus Covid 19 yang dialami makin banyak oleh penduduk Indonesia. Hal tersebut terjadi karena ada dua pendorong utama yaitu esting atau pemeriksaan RT-PCR yang memang semakin meningkat jumlahnya. Semakin banyak orang yang dites, maka semakin tinggi pula peluang temuan kasus positif Covid-19. Alasan selanjutnya adalah masih banyaknya masyarakat yang abai terhadap pelaksanaan protokol kesehatan. peningkatan jumlah kasus aktif di Indonesia ini disebabkan kepatuhan masyarakat dalam menjalankan protokol kesehatan yang masih rendah. Banyaknya larangan dan 
protocol dalam mencegah penularan wabah Covid 19 masih belum dipatuhi oleh masyarakat secara disiplin.

Tabel 3. Parameter model yang terbentuk

\begin{tabular}{cccccccc}
\hline Model & \multicolumn{4}{c}{ Parameter } & $\begin{array}{c}\text { Waktu } \\
\text { Kasus Baru } \\
\text { Tertinggi }\end{array}$ & $\begin{array}{c}\text { Jumlah } \\
\text { Kasus } \\
\text { Tertinggi }\end{array}$ & $\begin{array}{c}\text { Waktu Kasus } \\
\text { Covid 19 } \\
\text { Berakhir }\end{array}$ \\
\hline 1 & 1.000 .000 & 0 & 257 & 47,4007 & 257 & 5,274 & 730 \\
2 & 1.100 .000 & 0 & 264 & 48,1129 & 264 & 5,716 & 748 \\
3 & 1.200 .000 & 0 & 270 & 48,7059 & 270 & 6,159 & 763 \\
4 & 1.300 .000 & 0 & 276 & 49,2073 & 276 & 6,605 & 777 \\
5 & 1.400 .000 & 0 & 281 & 49,6367 & 281 & 7,051 & 790 \\
6 & 1.500 .000 & 0 & 286 & 50,0087 & 286 & 7,499 & $>800$ \\
\hline
\end{tabular}

Keterangan: * locked value

Ketika total Covid 19 di Indonesia mencapai 1.000.000 kasus covid maka dapat diperkirakan puncak terjadinya kasus covid 19 tertinggi adalah hari ke 257 dimulai pada saat awal Covid 19 teridentifikasi di Indonesia dengan besarannya sebesar 5.274 kasus namun akan diperkirakan berakhir pada hari ke 730. Apabila bergeser menjadi 1.100.000 maka puncaknya akan semakin mundur menjadi hari ke 264 dengan jumlah kasus tertinggi sebesar 5.716 kasus dan lebih lambat perkiraan berakhirnya yaitu di hari ke 748. Ketika mencapai 1.200.000 total kasus maka puncak harinya menjadi hari ke 270 yang mana nilai tertinggi dari kasus Covid 19 yang terjadi adalah 6.159 kasus dengan berakhirnya diperkirakan pada waktu ke hari 763. Ketika total kasus Covid 19 mecapai 1.300.000 kasus, maka puncak Covid akan terjadi pada hari ke 276 dengan kasus tertinggi diprediksi sebanyak 6.605 dengan hari berakhir di hari ke 777. Pada saat total kasus Covid 19 di Indonesia meningkat menjadi 1.400 .000 maka puncak kasus baru tertinggi berada di hari ke 281 dengan total jumlah kasus tertinggi sebesar 7.051 yang berakhir di hari ke 790. Dan terakhir, jika Indonesia memiliki total kasus Covid 19 sebesar 1.500 .000 maka puncak terbesar kasus covid 19 akan diprediksi pada hari ke 286 dengan kasus sebanyak 7,499 dan akan berakhir pada hari lebih dari ke 800. Akurasi hasil peramlan tersebut dapat dilihat pada Tabel 4.

Tabel 4. Nilai mean error persentage error (MAPE) nonlinear regresi logistic indonesia

\begin{tabular}{ccccccc}
\hline \multirow{2}{*}{ Model } & \multirow{2}{*}{ Training } & \multicolumn{5}{c}{ Forecast data testing } \\
\cline { 3 - 7 } & & 1 & 3 & 7 & 14 & 21 \\
\hline Model 1 & 79,62 & 0,764730 & 0,953458 & 1,156478 & 1,608403 & 2,224457 \\
Model 2 & 82,36 & 1,184705 & 1,408208 & 1,683340 & 2,273181 & 3,042883 \\
Model 3 & 84,64 & 1,525319 & 1,777708 & 2,112945 & 2,818437 & 3,718038 \\
Model 4 & 86,57 & 1,807104 & 2,083859 & 2,469940 & 3,273761 & 4,284556 \\
Model 5 & 88,22 & 2,044078 & 2,341658 & 2,771298 & 3,659715 & 4,766729 \\
Model 6 & 89,65 & 2,246137 & 2,561717 & 3,029083 & 3,991037 & 5,182105 \\
\hline
\end{tabular}

Berdasarkan Tabel 4 terlihat bahwa semakin besar kita berspekulasi terhadap total kasus Covid 19 yang akan dialami Indonesia, maka semakin tinggi pula nilai MAPE secara keseluruhan. Begitu pula semakin panjang kita melakukan peramalan pada 
masing masing model maka semakin besar pula nilai MAPE out sampel yang dihasilkan. Hasil peramalan dari model yang terbentuk dapat disandingkan dengan data aktual yang dapat digambarkan sesuai pada Gambar 3.

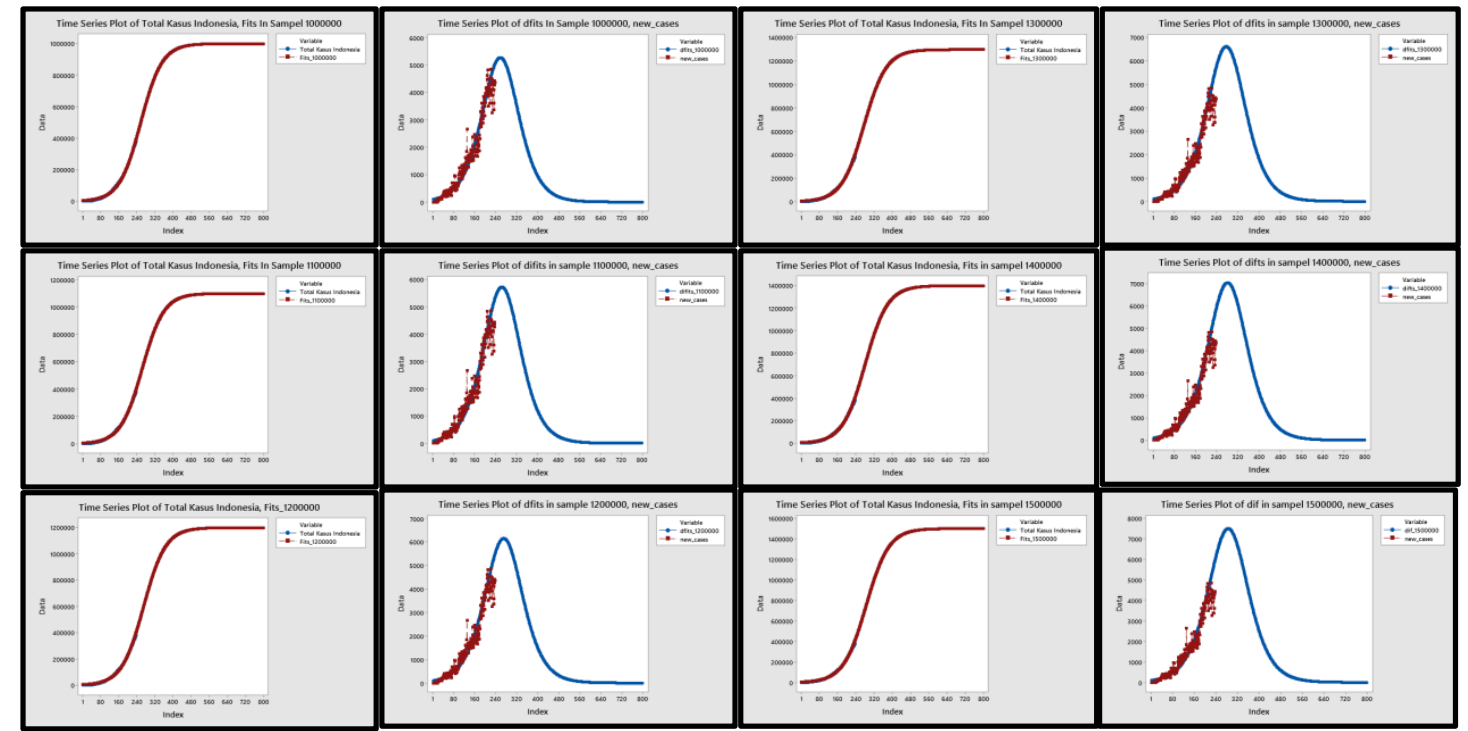

Gambar 3. Grafik fits model dengan total kasus covid 19 dan dfits dengan kasus baru covid 19 di indonesia

Dalam pembuatan model Nonlinear Regression Logistic dengan data Negara Prancis diperlukan identifikasi parameter theta guna mendapatkan model yang fit. Mengingat kasus Covid 19 di Prancis sudah tergolong two wave maka harus menggunakan dua model Nonlinear Regression Logistic. Pada model ini yang menggunakan initial value hanya $\theta_{4}$ dan $\theta_{8}$ dengan memberi nilai masing masing 1 . Karena total kasus pada Negara Prancis sudah menginjak satu juta total kasus dimana belum mencapai puncak, maka digunakan spekulasi total kasus yang akan terjadi yaitu 4.000.000 dan 5.000.000 kasus. Puncak gelombang pertama pada kasus Covid 19 di Prancis diketahui pada hari ke 68 sedangkan untuk puncak kedua masih belum diketahui. Oleh karena itu pada $\theta_{7}$ diberikan nilai puncak dimana setelah dikurangi puncak pada gelombang pertama yaitu 167. Untuk lebih rincinya dapat dilihat pada Tabel 5 dan 6.

Tabel 5. Pembentukan model nonlinear regression logistic dengan initial value $\theta_{4}$ dan $\theta_{8}$

\begin{tabular}{ccccccccc}
\hline \multirow{2}{*}{ Prakiraan Kasus } & \multicolumn{10}{c}{ Parameter } \\
\cline { 2 - 9 } & $\theta_{1}{ }^{*}$ & $\theta_{2}{ }^{*}$ & $\theta_{3}{ }^{*}$ & $\theta_{4}$ & $\theta_{5}{ }^{*}$ & $\theta_{6}{ }^{*}$ & $\theta_{7}$ & $\theta_{8}$ \\
\hline 4.000 .000 & 200.000 & 0 & 68 & 1 & 4.000 .000 & 0 & 167 & 1 \\
5.000 .000 & 155.000 & 0 & 68 & 1 & 5.000 .000 & 0 & 167 & 1 \\
\hline
\end{tabular}

Keterangan: * locked value

Tabel 6 merupakan hasil dari model nonlinear regression logistic dengan 2 kemungkinan total kasus Covid 19 yang akan dialami oleh Negara Prancis. Mengingat Prancis belum mengalami tanda tanda penurunan maka diberikan beberapa spekulasi pesimistis apabila kasus Covid 19 yang dialami makin banyak oleh penduduk Prancis. Hal 


\section{I.G.B.N. Diksa}

tersebut terjadi karena pengabaian akan aturan jarak sosial, sehingga korban yang terinfeksi kasus Covid 19 menjadi meningkat secara drastis [14].

Tabel 6. Parameter model yang terbentuk

\begin{tabular}{|c|c|c|c|c|c|c|c|c|c|c|c|}
\hline \multirow[b]{2}{*}{ Model } & \multicolumn{8}{|c|}{ Parameter } & \multirow{2}{*}{$\begin{array}{c}\text { Waktu } \\
\text { Kasus } \\
\text { Tertinggi }\end{array}$} & \multirow{2}{*}{$\begin{array}{c}\text { Jml } \\
\text { Kasus } \\
\text { Tertingg } \\
\text { i }\end{array}$} & \multirow{2}{*}{$\begin{array}{l}\text { Waktu } \\
\text { Kasus } \\
\text { Covid } 19 \\
\text { Berakhir }\end{array}$} \\
\hline & $\theta_{1}^{*}$ & $\theta_{2}^{*}$ & $\theta_{3}{ }^{*}$ & $\theta_{4}^{*}$ & $\theta_{5}{ }^{*}$ & $\theta_{6}^{*}$ & $\theta_{7}$ & $\theta_{8}^{*}$ & & & \\
\hline 1 & 200.000 & 0 & 68 & 29 & 4.000 .000 & 0 & 223 & 18 & 289 & 55.470 & 515 \\
\hline 2 & 155.000 & 0 & 68 & 11,24 & 5.000 .000 & 0 & 239 & 23,57 & 292 & 55.548 & 515 \\
\hline
\end{tabular}

Keterangan: * locked value

Ketika Prancis dispekulasikan akan terjadi total kasus covid 19 sebanyak 4.000.000 maka akan mengakibatkan jumlah kasus tertinggi sebanyak 55.470 yang mana puncak tertinggi tersebut diramalkan pada hari ke 289. Ketika bergeser pada 5.000.000 total kasus maka waktu puncak kasus baru tertinggi berada pada hari ke 292 dengan jumlah sebesar 55.548 .

Model 1

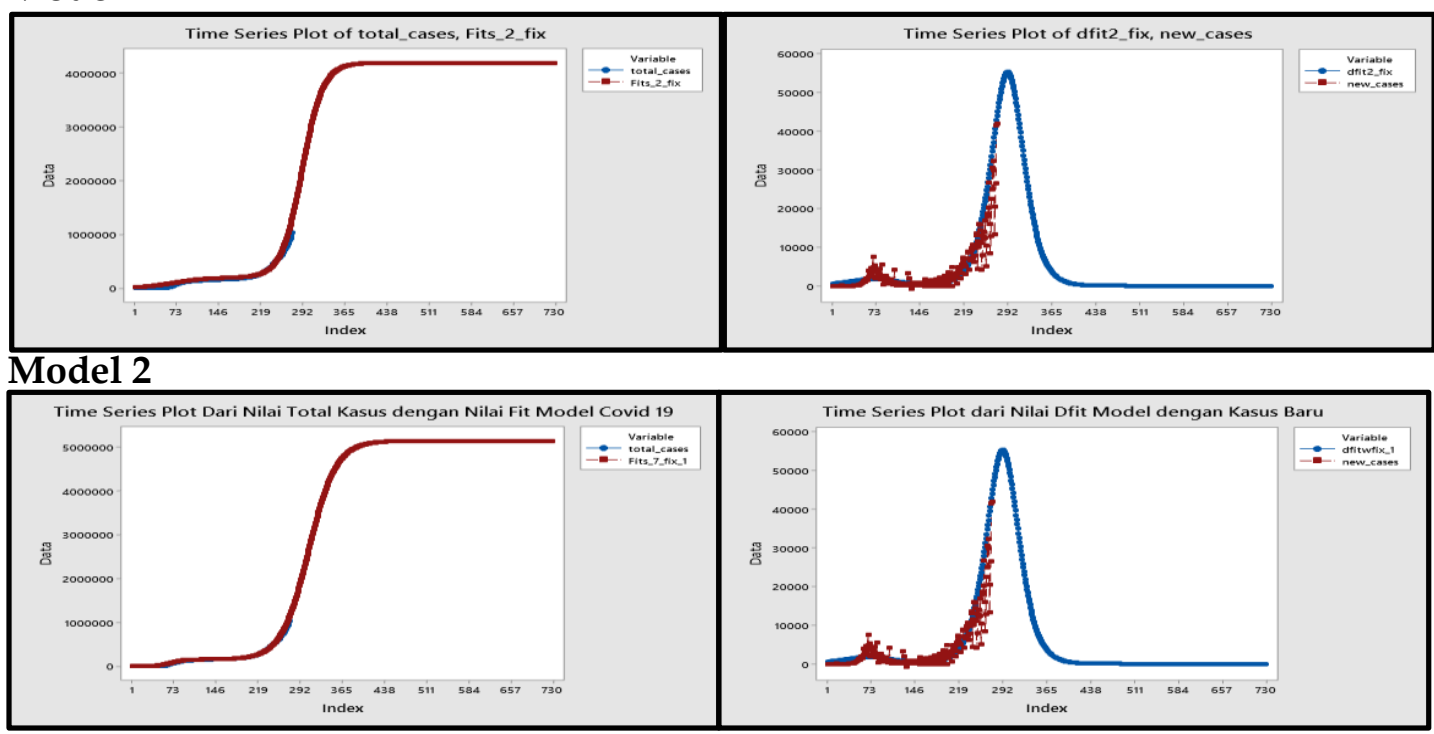

Gambar 4. Grafik fits model dengan total kasus covid 19 dan dfits dengan kasus baru covid 19 di Prancis

Berdasarkan Gambar 4. terlihat bahwa nilai prediksi (fit) yang dihasilkan oleh model beserta differencing di lag 1 telah sesuai dengan total kasus dan kasus baru yang terjadi di Prancis. Hal ini diperkuat dari MAPE hasil peramalan pada Tabel 7.

Tabel 7. Nilai mean error persentage error (MAPE) nonlinear reg logistic Prancis

\begin{tabular}{ccrrrrr}
\hline \multirow{2}{*}{ Model } & trainin & \multicolumn{5}{c}{ Forecast data testing } \\
\cline { 3 - 7 } & $\boldsymbol{g}$ & $\mathbf{1}$ & $\mathbf{3}$ & $\mathbf{7}$ & $\mathbf{1 4}$ & \multicolumn{1}{c}{$\mathbf{2 1}$} \\
\hline Model 1 & 52,65 & 7,42299 & 9,39475 & 12,60652 & 16,70086 & 19,79853 \\
Model 2 & 35,15 & 4,20085 & 5,54186 & 7,42246 & 9,06539 & 9,75442 \\
\hline
\end{tabular}


Bila dilihat dari nilai MAPE secara keseluruhan, Model 2 memiliki nilai MAPE yang lebih kecil. Model 2 merupakan model yang prediksi total kasus covid 19 yang terjadi di Prancis sebanyak 5.000.000 kasus. Berdasarkan panjangnya melakukan peramalan maka semakin panjang waktu kita meramal maka semakin besar juga nilai MAPE.

\subsection{Hybrid Model Nonlinear Regression Logistic and Doubel Exponential Smoothing (DES)}

Dalam pembentukan model hybrid digunakan residual dari model Nonlinear Regression Logistic untuk pembentukan model Double Exponential Smoothing. Ketika pembentukan model digunakan nilai alpha (level) dan lambda (trend) masing masing masing sebesar 0,94 dan 0,01. Berikut perbandingan nilai MAPE antara model nonLinear regression logistic dengan Model Hybrid Nonlinear Regression Logistic and Doubel Exponential Smoothing yang disajikan pada Tabel 8.

Tabel 8. MAPE nonlinear regression logistic (NRL) dan model hybrid NRL-DES

\begin{tabular}{|c|c|c|c|c|c|c|c|}
\hline \multirow{2}{*}{ Metode } & \multirow{2}{*}{ Model } & \multirow{2}{*}{ training } & \multicolumn{5}{|c|}{ Testing } \\
\hline & & & 1 & 3 & 7 & 14 & 21 \\
\hline \multicolumn{8}{|c|}{ PRANCIS } \\
\hline \multirow{2}{*}{$N R L$} & I & 52,65 & 7,42300 & 9,39475 & 12,60652 & 16,7009 & 19,7985 \\
\hline & II & 35,15 & 4,20080 & 5,54186 & 7,42246 & 9,06539 & 9,75442 \\
\hline \multirow{2}{*}{$N R L-D E S$} & I & 60,66 & 1,29882 & 1,37907 & 3,47188 & 7,42561 & 10,7651 \\
\hline & II & 26,67 & 0,20383 & 1,59995 & 3,61812 & 5,54264 & 6,51049 \\
\hline \multicolumn{8}{|c|}{ INDONESIA } \\
\hline \multirow{4}{*}{ NRL } & I & 79,62 & 0,76473 & 0,95346 & 1,15648 & 1,60840 & 2,22446 \\
\hline & II & 82,36 & 1,18471 & 1,40821 & 1,68334 & 2,27318 & 3,04288 \\
\hline & III & 84,64 & 1,52532 & 1,77771 & 2,11294 & 2,81844 & 3,71804 \\
\hline & IV & 86,57 & 1,80710 & 2,08386 & 2,46994 & 3,27376 & 4,28456 \\
\hline \multirow{8}{*}{ NRL-DES } & V & 88,22 & 2,04408 & 2,34166 & 2,77130 & 3,65972 & 4,76673 \\
\hline & VI & 89,65 & 2,24614 & 2,56172 & 3,02908 & 3,99104 & 5,18210 \\
\hline & I & 6,734 & 0,14117 & 0,33719 & 0,55524 & 1,03114 & 1,66826 \\
\hline & II & 7,119 & 0,17822 & 0,41033 & 0,70373 & 1,32271 & 2,11782 \\
\hline & III & 7,437 & 0,20890 & 0,47095 & 0,82708 & 1,56589 & 2,49442 \\
\hline & IV & 7,703 & 0,23471 & 0,52201 & 0,93114 & 1,77172 & 2,81434 \\
\hline & V & 7,929 & 0,25673 & 0,56558 & 1,02009 & 1,94815 & 3,08942 \\
\hline & VI & 8,124 & 0,27573 & 0,60320 & 1,09698 & 2,10104 & 3,32843 \\
\hline
\end{tabular}

Berdasarkan Tabel 8 terlihat bahwa metode hybrid Nonlinear Regression Logistic and Doubel Exponential Smoothing (DES) lebih efisien dibandingkan dengan model Nonlinear Regression Logistic. Hal ini dapat dibuktikan dengan nilai MAPE model hybrid sepanjang peramalan 1, 3, 7, 14 dan 21 hari yang akan datang lebih kecil dibandingkan model tunggal.

\section{Kesimpulan}

Model peramalan Hybrid Nonlinear Regression Logistic and Doubel Exponential Smoothing efisien digunakan dalam peramalan kasus Covid 19 di Indonesia dan Prancis. Terlihat 
bahwa nilai MAPE model hybrid jauh lebih kecil dibandingkan model tunggal. Berdasarkan hasil model hybrid dapat disimpulkan pula dengan metode yang sama namun dalam wave yang berbeda, jauh lebih efisien digunakan dalam kondisi daerah yang mengalami one wave pada kasus Covid 19. Indonesia dengan prediksi pesimistis sampai rentang 1.500.000 kasus diprediksi akan hilang pada hari lebih dari ke 800 hari dari awal mulia Covid 19 di Indonesia. Hasil ini berbeda jauh dengan Prancis yang mana tingkat pesimistis adalah 4.000.0000 dan 5.000.0000 namun dapat diramalkan dapat hilang dalam kurun waktu 515 hari atau kurang dari 2 tahun. Hal ini menandakan bahwa solusi Prancis dalam menghadapi Covid 19 lebih efektif dan efisien dibandingkan Indonesia.

\section{Referensi}

[1] P. D. Pakan and U. N. Cendana, "Peramalan Kasus Positif di Indonesia Menggunakan LSTM 13," vol. 6, no. 1, pp. 12-15, 2020.

[2] N. Hasan, "A Methodological Approach for Predicting COVID-19 Epidemic Using EEMD-ANN Najmul Hasan Abstract" Internet of Things, p. 100228, 2020, doi: 10.1016/j.iot.2020.100228.

[3] S. Harini, "Identification COVID-19 Cases in Indonesia with The Double Exponential Smoothing Method," vol. 6, no. 1, pp. 66-75, 2020.

[4] S. Singh, K. S. Parmar, J. Kumar, S. Jitendra, and S. Makkhan, “Development of New Hybrid Model of Discrete Wavelet Decomposition and Autoregressive Integrated Moving Average (ARIMA) Models in Application to One Month Forecast the Casualties Cases of COVID-19," Chaos, Solitons Fractals Interdiscip. J. Nonlinear Sci. Nonequilibrium Complex Phenom., p. 109866, 2020, doi: 10.1016/j.chaos.2020.109866.

[5] E. Gjika, A. Ferrja, and A. Kamberi, "A study on the efficiency of hybrid models in forecasting precipitations and water inflow Albania case study," Adv. Sci. Technol. Eng. Syst., vol. 4, no. 1, pp. 302-310, 2019, doi: 10.25046/aj040129.

[6] P. Wang, X. Zheng, J. Li, and B. Zhu, "Prediction of epidemic trends in COVID-19 with logistic model and machine learning technics," Chaos, Solitons and Fractals, vol. 139, p. 110058, 2020, doi: 10.1016/j.chaos.2020.110058.

[7] A. Mwakisisile and A. Mushi, "Mathematical Model for Tanzania Population Growth," Tanzania J. Sci., vol. 45, no. 3, pp. 346-354, 2019.

[8] C. V. Hudiyanti, F. A. Bachtiar, and B. D. Setiawan, "Perbandingan Double Moving Average dan Double Exponential Smoothing untuk Peramalan Jumlah Kedatangan Wisatawan Mancanegara di Bandara Ngurah Rai," J. Pengemb. Teknol. Inf. dan Ilmu Komput., vol. 3, no. 3, pp. 2667-2672, 2019.

[9] P. G. Zhang, "Time series forecasting using a hybrid ARIMA and neural network model," Neurocomputing, vol. 50, pp. 159-175, 2003, doi: 10.1016/S09252312(01)00702-0.

[10] D. I. Purnama and O. P. Hendarsin, "Peramalan Jumlah Penumpang Berangkat Melalui Transportasi Udara di Sulawesi Tengah Menggunakan Support Vector Regression (SVR)," Jambura J. Math., vol. 2, no. 2, pp. 49-59, 2020, doi: 10.34312/jjom.v2i2.4458. 
[11] M. N. Mara and N. Satyahadewi, "Kajian Teoritis Hybridizing Exponential Smoothing dan Neural Network untuk Peramalan Data Runtun Waktu", Bimaster Ilmiah Mat. Stat. dan Terapannya, vol. 02, no. 3, pp. 205-210, 2013.

[12] E. Pujiati, D. Yuniarti, and R. Goejantoro, "Peramalan Dengan Menggunakan Metode Double Exponential Smoothing Dari Brown (Studi Kasus: Indeks Harga Konsumen (IHK) Kota Samarinda)," J. Eksponensial, vol. 7, no. 1, pp. 33-40, 2016.

[13] Z. Hajirahimi and M. Khashei, "Hybrid structures in time series modeling and forecasting: A review," Eng. Appl. Artif. Intell., vol. 86, no. July, pp. 83-106, 2019, doi: 10.1016/j.engappai.2019.08.018.

[14] O. C. A. ogwa, C. Eze, and C. R. O. nkwo, "Modeling the Cases of Road Traffic Crashes: A Case of Exponential Smoothing Approach," Int. J. Math. Trends Technol., vol. 65, no. 1, pp. 46-52, 2019, doi: 10.14445/22315373/ijmtt-v65i1p508.

[15] R. Fajri and T. M. Johan, "Implementasi Peramalan Double Exponential Smoothing Pada Kasus Kekerasan Anak Di Pusat Pelayanan Terpadu Pemberdayaan Perempuan Dan Anak," J. ECOTIPE, vol. 4, no. 2, pp. 6-13, 2017, doi: 10.33019/ecotipe.v4i2.6.

[16] V. N. Fitriani and K. D. Purnomo, "Estimasi Solusi Model Pertumbuhan Logistik dengan Metode Ensemble Kalman Filter Solution Estimation of Logistic Growth Model with Ensemble Kalman Filter Method," J. Ilmu Dasar, vol. 14, no. 2, pp. 8590, 2013. 